\title{
Professional Development of Digital Competences: Standardised Frameworks Supporting Evolving Digital Badging Practices
}

\author{
Jaana Kullaslahtia , Sanna Ruhalahtia \\ and Sanna Brauer ${ }^{\mathrm{b} *}$ \\ ${ }^{a}$ HAMK School of Professional Teacher Education \\ 35 A Visamäentie, Hämeenlinna, 13100, Finland \\ ${ }^{b}$ Oulu University of Applied Sciences, \\ School of Professional Teacher Education \\ 4 Kiviharjuntie, Oulu, 90220, Finland
}

Digital competences of teachers at vocational institutions and universities of applied sciences will be supported by digital open badges to a greater extent in the future. Various digital pedagogical competence frameworks have been developed to support professional teachers' effective and meaningful criterion-based professional development of digital pedagogical competences. European frameworks published in recent years outline how a digitally competent educational organisation (DigCompOrg) and digitally competent teaching staff (DigCompEdu) should look, encouraging organisations to ensure competences of their staff and to develop national solutions to ensure digital competence.

In this study, we investigated how digital open badges developed for teaching personnel in Finland correspond with these European frameworks. This article presents a case study showing how digital open badges for Finnish teachers' digital competence correspond to the standardised DigCompEdu framework. This qualitative study used a deductive content analysis to discern relationships between the data and the existing frameworks and to quantify phenomena. The results indicate that Finnish teachers' badges best correspond to the digital learning environment as well as to teaching and learning. However, the developed badges correspond only marginally to the following competence descriptions: areas of assessment, learner empowerment and the facilitation of digital competence.

Keywords: digital open badges, digital pedagogical competences, competence frameworks, DigCompEdu, professional development.

Research area: pedagogy.

(c) Siberian Federal University. All rights reserved

* Corresponding author E-mail address: sanna.brauer@oamk.fi

This work is licensed under a Creative Commons Attribution-NonCommercial 4.0 International License (CC BY-NC 4.0). 
Citation: Kullaslahti, J., Ruhalahti, S., Brauer, S. (2019). Professional development of digital competences: standardised frameworks supporting evolving digital badging practices. J. Sib. Fed. Univ. Humanit. soc. sci., 12(2), 175-186. DOI: 10.17516/1997-1370-0387.

\section{Professional Teachers' Digital Competence}

The European Reference Framework of Key Competences for Lifelong Learning (European Union, 2007) described "competence" as the required knowledge but also skills, attitudes and the ability to apply learning outcomes as is appropriate to the context (e.g., working life) (Cedefop, 2014). In this study, we connect the concept of competence with competence frameworks that provide tools to enhance professional teachers digital pedagogical competence. The concept of competence is separated, by paradigmatic difference, from the concept of competency, as competency refers to the potential of an individual as a whole (Mäkinen \& Annala, 2010).

Professional teachers' competence in digital pedagogy is seen as a combination of professional or substantial, pedagogical and technological expertise (e.g., Kullaslahti, 2011; Guerrero, 2005; Koehler, Mishra, \& Cain, 2013). Kullaslahti (2011) added teachers' personal attributes to the list, that is, the continuous use of digital pedagogy and the development of one's own work in cooperation with colleagues and the world of work. Context was also added to the description of competence based on the teacher's role and tasks in his or her own organisation (Krumsvik, 2014; Kullaslahti, 2011; Lund et al., 2014). According to the European digital framework (Kampylis, Punie, \& Devine, 2015), educational organisations should describe, maintain and evaluate their staff's digital competence as well as that of their students. At present, Finland does not have formal requirements or standards for teachers' competence (European Commission/ EACEA/ Eurydice, 2018).

\section{Standardised Competence Frameworks in Europe}

Various digital pedagogical competence frameworks have been developed to support teachers, educational organisations and legislators in delivering the effective and meaningful criterion-based professional development of different competences (Kools \& Stoll, 2016). In Finland, different initiatives to promote teachers' professional development have been applied based on the United Nations Educational, Scientific and Cultural Organization's (UNESCO, 2011) Information and Communications Technology Competency Framework for Teachers (ICT-CFT) as national guidelines. UNESCOs' ICT-CFT outlines the competences required to teach effectively with 
ICT. The competence framework advances from understanding technology towards the development of learning organisations.

The three successive stages of development aim to support teachers using ICT in enhancing students' collaboration, creativity and problem solving. These stages of teachers' professional development have been augmented at the European level by the Digital Competence Framework for Educators (DigCompEdu), who proposed educatorspecific digital competence (Redecker, 2017) based on the competence descriptions of a digital citizen (DigComp), an educational organisation (DigCompOrg; see Kampylis, Punie, \& Devine, 2015) and consumers (DigCompConsumers). The DigCompEdu aims to inform how digital technologies can be used to enhance and innovate education and training. The framework responds to Europe's need to define digital competence specific to teachers and to harness the potential of digitalisation to improve several aspects of education. The scope is not entirely on educators' pedagogical competences; it also allows for the need for professional development to be noted as well as the different intended competences of a learner.

\section{Digital Open Badges}

Digital badges (e.g., Mozilla Open Badges) enable the identification and recognition of different competences acquired in formal or non-formal education (Devedžić \& Jovanović, 2015; Knight \& Casilli, 2012). Badges contain metadata about the recipient's competence, such as learning outcomes, and the expertise criteria required (Newby et al., 2016). The issuer of the badge (i.e., the identifier and recogniser of competence) can be, for example, an educational organisation or business. It is up to the badge applicant to present the evidence to earn a badge in accordance with the badge criteria. It is important to note that not all digital badges are based on competence identification and recognition; they can also be given for participation in training or function as a certificate for a specified time period (Brauer \& Ruhalahti, 2014).

The Open Badge Infrastructure allows learners to collect multiple badges from various issuers (Devedžić \& Jovanović, 2015). The use of badges and their public distribution is decided by the person who owns the badge. Badge criteria explain, in detail, the acquired competences, and a badge recipient collects the badges he or she earns within his or her own personalised online repository. It is possible to add online evidence of a badge earner's expertise (Casilli \& Hickey, 2016) or build a mini portfolio around a specific theme and related competences (Brauer, Ruhalahti, \& Pakanen, 2018). In the future, digital open badges will be integrated into different 
learning environments as well as nationwide solutions for student management and the blockchain architecture of the digital learning ecosystem (Brauer, 2019).

\section{Digital Badges in the Professional Development of Vocational Teachers}

Comprehensible badge criteria help students understand their existing competences and can inform pathways to deepen these (Abramovich, 2016; Brauer, 2019). The Teachers' Badges Project aims to create and establish a national digital badge system to support the recognition and acknowledgment of professional competences for vocational teachers (HAMK, 2018). The Teachers' Badges Project originated from the initial success of the Learning Online professional development programme (PDP) and aims to promote the competence-based approach to vocational teacher programmes (Isacsson, Stigmar, \& Amhag, 2018). In the Teachers' Badges Project, the Learning Online badge constellation represents one part of the competence framework for future teachers. However, the competences required of vocational pre- and in-service teachers presents a more complex vision of the competence development continuum of vocational teachers.

\section{Statement of the Problem}

Teachers' competences in ICT and their digital pedagogical competences have been examined in recent years (e.g., Hietikko, Ilves, \& Salo, 2016; Ruhalahti \& Kenttä, 2017; Koramo, Brauer, \& Jauhola, 2018) in the educational context of Finnish higher education (e.g., Kullaslahti, Karento, \& Töytäri, 2015). Recent studies (Brauer et al., 2017; Brauer, Kettunen, \& Hallikainen, 2018; Brauer, Korhonen, \& Siklander, 2019; Brauer, Ruhalahti, \& Hallikainen, 2018) emphasise how digital open badges and different standardised competence frameworks aim to define the digital pedagogical skills and knowledge needed in working life, existing frameworks were compared to determine the direction of standardisation competence frameworks in Finland. This study aims to address how digital open badges for Finnish teachers' digital competence correspond to the standardised DigCompEdu framework.

\section{Context of the Study}

The context of the study is Finnish higher education, especially professional teacher education operating under universities of applied sciences. This study is a part of the eAMK and the Teachers' Badges Project in Finland funded by the 
Ministry of Education and Culture. The eAMK project focuses on developing the digital courses offered by all Finnish universities of applied sciences. The Teachers' Badges Project focuses on the identification and recognition of competences for professional teacher education and the development of digital competence badges. In addition, the data of this study consists of digital badges for vocational teachers' digital competence (Learning Online), and competence badges for DigTeacher specialised training for vocational teachers related to digital disruption in work and learning in Finland.

\section{Data}

A key theme of the constructions studied was vocational teachers' professional development of digital, pedagogical and ICT competences with digital open badges. The data consists of digital badges for professional teachers' digital competences (Learning Online), badges for the development of the digital competence of teaching staff at universities of applied sciences (eAMK) and competence badges for DigTeacher specialised training $(n=101)$. The sizes and scope of the badges under analysis varied, as well as the processes and methods used to identify and demonstrate competences. The aim was to answer the following question: how do digital open badges for Finnish teachers' digital competences correspond to the DigCompEdu framework?

\section{Data Analysis}

The method used was deductive content analysis, which takes the source material as a starting point and examines it in relation to the theoretical framework of the study (Schreier, 2012). The deductive categorisation and quantification of this study was based on the DigCompEdu framework. According to deductive analysis, the categorisation was conducted against the framework's six areas of competences: professional engagement, digital resources, teaching and learning, assessment, empowering learners and facilitating learners' digital competence, as well as the related subcategories. The authors created a coding scheme that guided the process and aimed to increase the validity of the research. The analysis of the material commenced by reading the badges' descriptions of competence and the instructions for identifying and demonstrating competence. The badges were divided into the aforementioned classes based on their descriptions. Based on the descriptions, some badges could have been placed in various classes, but a choice was made based on the primary emphasis. 


\section{Results and Conclusions}

The analysis provides a clear view of the current situation in terms of the development of digital open badges for Finnish professional teachers' digital competences (Table 1). Most of the badges developed so far correspond with the DigCompEdu framework's first three areas of competences: digital resources, teaching and learning and professional engagement.

Table 1. Quantified Data Analysis of Vocational Teachers' Digital Badges by Competence Area According to the DigCompEdu Framework

\begin{tabular}{|c|c|c|c|}
\hline \multicolumn{4}{|c|}{ Area of Competence in Accordance with the DigCompEdu Framework } \\
\hline Area of Competence & $\begin{array}{l}\text { Quantity } \\
\text { (n) }\end{array}$ & Area of Competence & $\begin{array}{l}\text { Quantity } \\
\text { (n) }\end{array}$ \\
\hline 1. Professional engagement & 2 & 4. Assessment & 0 \\
\hline 1.1. Organisational communication & 9 & 4.1. Assessment strategies & 3 \\
\hline 1.2. Professional collaboration & 9 & 4.2. Analysis of evidence & 0 \\
\hline 1.3. Reflective practice & 2 & 4.3. Feedback and planning & 1 \\
\hline 1.4. Digital CDP & 5 & & \\
\hline Total & 27 & Total & 4 \\
\hline 2. Digital resources & 3 & 5. Empowering learners & 0 \\
\hline 2.1. Selection & 9 & 5.1. Accessibility and inclusion & 0 \\
\hline 2.2. Creation and modification & 17 & $\begin{array}{l}\text { 5.2. Differentiation and } \\
\text { personalisation }\end{array}$ & 1 \\
\hline $\begin{array}{l}\text { 2.3. Management, protection and } \\
\text { sharing }\end{array}$ & 6 & 5.3. Actively engaging learners & 3 \\
\hline Total & 35 & Total & 4 \\
\hline 3. Teaching and learning & 7 & $\begin{array}{l}\text { 6. Facilitating learners' digital } \\
\text { competence }\end{array}$ & 0 \\
\hline 3.1. Teaching & 12 & 6.1. Information and media literacy & 1 \\
\hline 3.2. Guidance & 4 & 6.2. Communication & 0 \\
\hline 3.3. Collaborative learning & 7 & 6.3. Content creation & 0 \\
\hline \multirow[t]{2}{*}{ 3.4. Self-regulated learning } & 0 & 6.4. Responsible use & 0 \\
\hline & & 6.5. Digital problem solving & 0 \\
\hline Total & 30 & Total & 1 \\
\hline \multicolumn{3}{|l|}{ Grand Total } & 101 \\
\hline
\end{tabular}

In Finland, the focus has been on the nationwide development of teachers' competences in digital operating environments using different tools, producing and selecting digital material and becoming familiar with the operating practices of the digital environment. In the sector of teaching, the emphasis is on teaching rather than on the areas of collaborative learning or self-regulation. In terms of professional 
engagement, the badges were split into different areas. Fewer badges were issued, however, for personal competences and the development of practices. Badges created for developing the competence of staff at the universities of applied sciences also reflect the development objectives of communal work, team teaching and networking in universities. In total, 92 badges were placed in these three teacher-centred competence areas.

In the assessment category, learner empowerment and the facilitation of digital competences, the existing badges corresponded only marginally to the competence descriptions of each section. Only four badges were placed in the assessment category. Competence-based assessment, the digital verification of competences and learning analytics are key areas for development, and the currently ongoing projects intend to produce badges for these areas. The category of empowering learners only received four badges, three of which described the activation of learners by digital means. Current development areas, such as accessibility and personalisation, will hopefully receive their own badges as a result of ongoing university projects. Only one badge was placed in the category of facilitating learners' digital competences. In a survey completed as a part of the eAMK project (Kopeli, 2018), students' digital competences were not found to develop sufficiently in all the different areas during their studies. Only nine of the digital badges were placed in these three more studentcentred competence areas.

The DigCompEdu framework further labels each competence area to capture the particular focus of digital technology use that is typical in that area. The analysed digital badges were compared with these labels, and Fig. 1 shows the differences of analysed data and national projects.

Compared with the DigCompEdu framework, the badges best correspond to the digital learning environment as well as to teaching and learning. However, it should be noted that some of the badges were extensive in terms of their scopes, objectives and ways to indicate competence, and some contained elements from different areas of the framework. The results aim to inform competence frameworks that can be used to enhance and innovate vocational teacher programmes. This study responds, on the national level, to educators' need to define competences that are specific to vocational teachers and to harness the potential of digital open badges.

The next step is to continue the qualitative analysis of these badges and the definitions of competence descriptions, particularly in professional teacher education and continuing education and for the teaching staff at universities of applied sciences. 


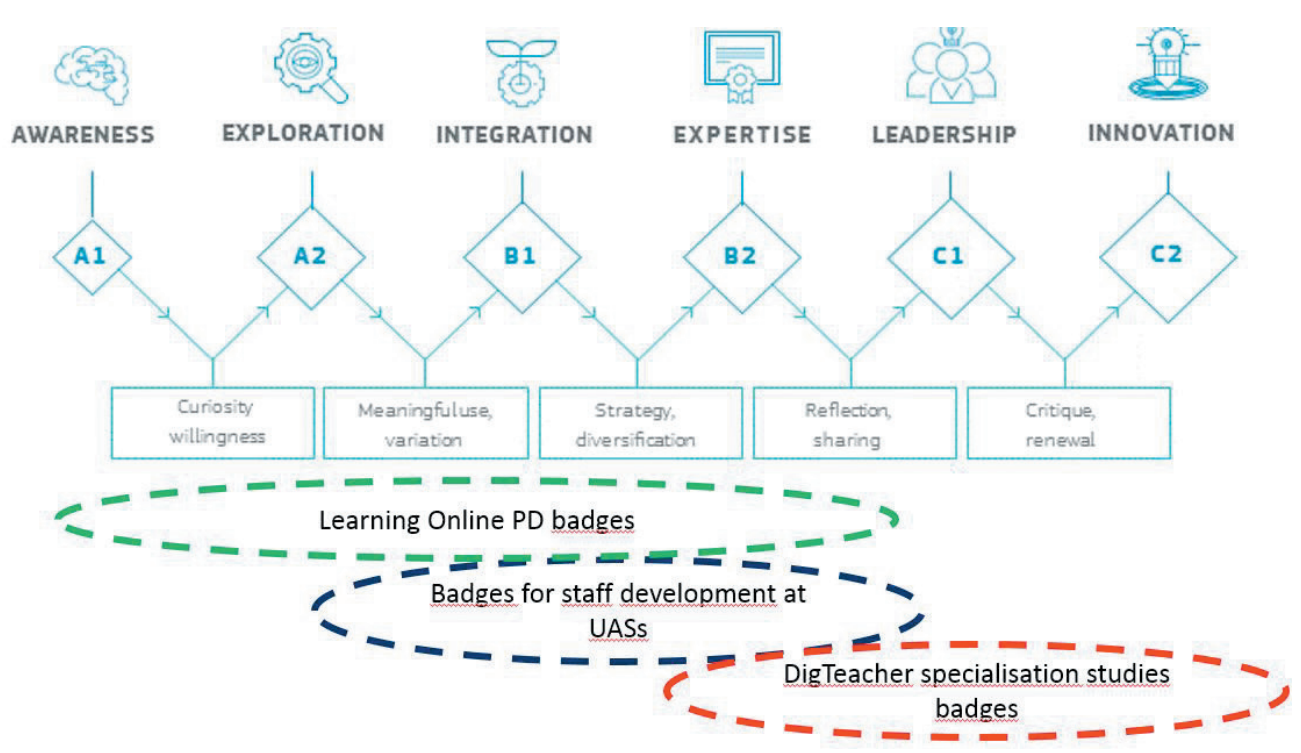

Fig. 1. Competence levels in comparison with the DigCompEdu framework

The DigCompEdu framework was developed to serve teachers at all levels of education; therefore, it does not display any special characteristics of different educational levels, such as work-related competence and research skills. Thus, the following question remains: how well do digital badges guide the development of educational organisations, their staff and their students towards meeting the competence requirements of the future?

All authors contributed equally to this work.

\section{References}

Abramovich, S. (2016). Understanding digital badges in higher education through assessment. In On the Horizon, 24 (1), 126-131.

Brauer, S. (2019). Digital Open Badge-Driven Learning - Competence-based Professional Development for Vocational Teachers (doctoral dissertation). Acta Universitatis Lapponiensis 380. http://urn.fi/URN:ISBN:978-952-337-110-1.

Brauer, S., Kettunen, J. \& Hallikainen, V. (2018). “Learning Online” for Vocational Teachers - Visualisation of Competence-based-approach in Digital Open BadgeDriven Learning. In The Journal of Professional and Vocational Education: Vocational education and training in the Nordic countries, 20(2), 13-29.

Brauer, S., Korhonen, A-M. \& Siklander, P. (2019). Online scaffolding in digital open badge-driven learning. Educational Research. DOI: 10.1080/00131881.2018.1562953. 
Brauer, S. \& Ruhalahti, S. (2014). Osoita osaamisesi osaamismerkein [Show your competence with digital badges]. In A-M. Korhonen \& S. Ruhalahti (Eds.). Oppimisen digiagentit [Digital agents of learning] (HAMK e-publications 40/2014), 87-92.

Brauer, S., Ruhalahti, S. \& Hallikainen, V. (2018). Digital Professional Learning Triggers in an Online Badge Driven Process. Education in the North, 25(1-2), 64-86.

Brauer, S., Ruhalahti, S., \& Pakanen, L. (2018). Digitaaliset osaamismerkit - merkillä on väliä [Digital open badges - Badges do matter]. Available at: https:// pelimerkit.metropolia.fi/2018/05/07/digitaaliset-osaamismerkit-merkilla-on-valia/

Brauer, S., Siklander, P. \& Ruhalahti, S. (2017). Motivation in digital open badgedriven learning in vocational teacher education. In Ammattikasvatuksen Aikakauskirja, 19(3), 3.

Casilli, C., \& Hickey, H. (2016). Transcending conventional credentialing and assessment paradigms with information-rich digital badges. In The Information Society, 32 (2), 117-129.

Cedefop (2014). Terminology of European education and training policy: a selection of 130 terms. Luxembourg: Publications Office. Available at: http://www. cedefop.europa.eu/en/eventsand-projects/projects/validation-non-formal-andinformal-learning/european-inventory/european-inventory-glossary

Devedžić, V., \& Jovanović, J. (2015). Developing Open Badges: a comprehensive approach. In Educational Technology Research \& Development, 63(4), 603-620. http:// doi.org/10.1007/s11423-015-9388-3

European Commission/EACEA/Eurydice (2018). Teaching Careers in Europe: Access, Progression and Support. Eurydice Report. Luxembourg: Publications Office of the European Union.

European Union. (2007). The key competentences for life long learning - European reference framework. Available at: https://erasmusplus.org.uk/file/272/download

Guerrero, S.M. (2005). Teacher knowledge and new domain of expertise: pedagogical, technology knowledge. In Journal Educational Computing Research, $33(3)$

HAMK. (2018). Open Merkit-Teacher's Badges. Retrieved from HAMK University of Applied Sciences Webpage. Available at: http://www.hamk.fi/openmerkit.

Hietikko, P., Ilves, V. \& Salo, J. (2016). Askelmerkit digiloikkaan [Steps to digitalisation]. OAJ: OAJ:n julkaisusarja, 3. Available at: http://www.oaj.fi/cs/oaj/ OAJn\%20askelmerkit\%20digiloikkaa 
Isacsson, A., Stigmar, M., \& Amhag, L. (2018). The content, challenges and values that form Nordic Vocational Teacher Education. In The Journal of Professional and Vocational Education: Vocational education and training in the Nordic countries, 2, 38-50.

Kampylis, P., Punie, Y. \& Devine, J. (2015). Promoting Effective Digital-Age Learning. A European Frameworkfor Digitally-Competent Educational Organisations. EUR 27599EN.

Knight, E., \& Casilli, C. (2012). Mozilla Open Badges. In Game Changers. Education and information technologies, 279-284. EDUCAUSE. Available at: https:// net.educause.edu/ir/library/pdf/pub7203cs6.pdf

Koehler, M.J., Mishra, P. \& Cain W. (2013). What is Technological Pedagogical Content Knowledge (TPACK)? In Journal of Education, 193(3), 13-19.

Kopeli, M. (2018). Kysymys on huomisen digikyvykkyydestä. [It is all about future digital competence]. In AMK-lehti/UAS journal, 8(3). Available at: https://uasjournal. fi/3-2018/huomisen-digikyvykkyys/

Kools, M., \& Stoll, L. (2016). What Makes a School a Learning Organisation?. OECD Education Working Papers, 137. Paris: OECD Publishing. https://doi. org/10.1787/5jlwm62b3bvh-en

Koramo, M., Brauer, S., \& Jauhola, L. (2018). DIGAM - Digitalisaatio ammatillisessa koulutuksessa. [Digitalisation in vocational education]. Available at: https://www.oph.fi/julkaisut/2018/

Kullaslahti, J. (2011). Ammattikorkeakoulun verkko-opettajan kompetenssi ja kehittyminen. [Online-teachers' competence and development in universities of applied sciences]. Acta Universitatis Tamperensis; 1613. University Press, Tampere.

Kullaslahti, J., Karento, H. \& Töytäri A. (2015). Opettajien digipedagoginen osaaminen FUAS-liittouman ammattikorkeakouluissa. [Teachers' digipedagogical competence in FUAS institutions]. Häme University of Applied Sciences. In HAMK e-publications, 35. Available at: https://issuu.com/hamkuas/docs/fuas_opetajien_digipedagoginen_osaa

Krumsvik, R.J. (2014). Teacher educators' digital competence. In Scandinavian Journal of Education Research, 58(3), 269-280.

Lund, A., Furberg, A., Bakken, J. \& Engelien K.L. (2014). What does professional Digital Competence Mean in Teacher Education? In Nordic Journal of Digital Literacy, 9(4), 281-299.

Mäkinen, M. \& Annala, J. (2010). Osaamisperustaisen opetussuunnitelman monet merkitykset korkeakoulutuksessa [Various aspects of the competence-based curriculum in higher education]. In Kasvatus \& Aika, 4(4), 41-61. 
Newby, T., Wright, C., Besser, E., \& Beese, E. (2016). Passport to creating and issuing digital instructional badges. In D. Ifenthaler, N. Bellin-Mularski, \& D. Mah (Eds.). In Foundations of Digital Badges and Micro-Credentials: Demonstrating and Recognizing Knowledge and Competencies. New York: Springer.

Redecker, C. (2017). European Framework for the Digital Competence of Educators: DigCompEdu. Punie, Y. (ed) EUR 28775 EN. JRC107466. In Publications Office of the European Union, Luxembourg. Available at: https://ec.europa.eu/jrc/en/ publication/eur-scientific-and-technical-research-reports/european-framework-digitalcompetence-educators-digcompedu

Ruhalahti, S. \& Kentta, V. (2017). Ammatillisen koulutuksen digitalisaatio ja työelämäyhteistyö [Digitalisation and collaboration with the world of work in vocational education] In National Board of education, 2017:18.

Schreier, M. (2012). Qualitative content analysis in practice. London, United Kingdom: Sage.

UNESCO. (2011). UNESCO ICT Competency Framework for Teachers. Available at: http://unesdoc.unesco.org/images/0021/002134/213475e.pdf

\title{
Профессиональное развитие цифровых компетенций: стандартизированные рамки для поддержки \\ развивающихся практик применения \\ цифровых бейджей
}

\author{
Я. Кулласлахти ${ }^{\mathrm{a}}$, С. Рухалахти ${ }^{\mathrm{a}}$, С. Брауэр ${ }^{\sigma}$ \\ ${ }^{a}$ Институт профессионального педагогического \\ образования \\ Финляндия, 13100, Hämeenlinna, Visamäentie, 35 A \\ ${ }^{6}$ Университет прикладных наук Оулу \\ Институт профессионального педагогического \\ образования \\ Финляндия, 90220, Оулу, Kiviharjuntie, 4
}

Цифровые компетенции преподавателей колледжей и университетов прикладных наук будут в дальнейшем поддерживаться открытыми ияифровыми бейджами. Уже разработаны различные наборы ичирровых педагогических компетенций на основе критериев, обеспечивающих поддержку эффективного профессионального развития преподавателей. Существующие европейские рамки лищь в общих чертах предъявляют требования к иифровым компетенциям образовательных организаций 
u преподавательских кадров (DigCoтpEdu), поощряя первые к развитию компетеничй сотрудников и разработке национальной политики обеспечения иуифровизации.

В настоящем исследовании авторы изучили, как открытые циифровые бейджи, разработанные для преподавателей Финляндии, соответствуют указанным европейским стандартам. Здесь представлен кейс, показывающий, такие бейджи могут способствовать росту циирровой компетентности финских учителей до уровня стандартизированной рамки DigCoтpEdu. Для выявления взаимосвязей между данными и существующими рамками компетенщий использовали качественный метод дедуктивного контент-анализа. Результаты его показывают, что бейджи финских учителей лучше всего корреспондируют с иифровой средой, а также с преподаванием и обучением. Тем не менее они лишь незначительно поддерживают следующие компетенции: оценку, расширение возможностей учашихся и повышение уровня цифровой компетенции преподавателей.

Ключевые слова: открытые циирровые бейджи, циифровые компетенции преподавателей, рамка компетенций, DigCoтpEdu, повыщение квалификаичи.

Научная специиальность: 13.00.00 - педагогические науки. 